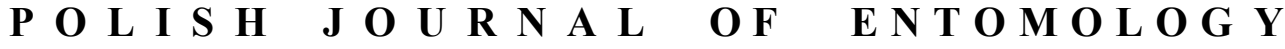

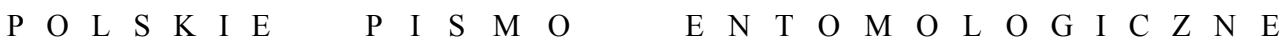

VOL. 82: 379-388

Gdańsk

31 December 2013

DOI: $10.2478 /$ pjen-2013-0001

\section{The flies (Diptera) say that amber from the Gulf of Gdańsk, Bitterfeld and Rovno is the same Baltic amber}

\author{
JACEK SZWEDO ${ }^{1} \&$ ELŻBIETA SONTAG ${ }^{2}$ \\ ${ }^{1}$ Department of Palaeozoology, Museum and Institute of Zoology, \\ Polish Academy of Sciences, Wilcza 64, 00-679 Warszawa, Poland, \\ e-mail: szwedo@miiz.waw.pl; \\ ${ }^{2}$ Museum of Amber Inclusions, University of Gdańsk, Wita Stwosza 59, 80-308 Gdańsk, \\ Poland, e-mail: elzbieta.sontag@ug.edu.pl
}

\begin{abstract}
Amber and its inclusions have been studied for over 200 years. Particular reverence was accorded the amber from the deposits around the Gulf of Gdańsk. As knowledge of amber increased, the problem of distinguishing amber from the various deposits along the Baltic Sea coast, but also in Germany, Belarus and Ukraine arose. Here we discuss the species composition of biting midges (Ceratopogonidae) from amber derived from different deposits, and discuss the use of regional names for Baltic amber yielding inclusions from the same taphocoenosis but of different geographical origin.
\end{abstract}

KEY WORDS: Baltic amber, deposits, Bitterfeld, Gdańsk Bay, Rovno, Ceratopogonidae, taphocoenosis.

Karabe. Bursztyn. Bursztyn iest żywicza z drzewa: iakoby drogi kamień. [Karabe. Amber. Amber is the resin from a tree: almost like a precious stone].

Falimirz S. 1543

\section{INTRODUCTION}

Amber from the Gulf of Gdańsk has attracted human attention for millennia. Long before the origin of modern taxonomy (LINNAEUS 1758) and the evolutionary revolution (DARWIN 1859), the small inclusions embedded in this perfect preservative were noticed and 
appreciated (e.g. MÜNSTER 1544, GöBel 1558, HARTMANN 1667, 1699, GREW 1681, Helwing 1717, Mercati 1717, Breyn 1728, DE Bonnac 1730, Sendelius 1742, FOTHERGILL 1746). The main origin of this appreciation was amber from the Gulf of Gdańsk area (e.g. BOCK 1767, 1783, GERMAR 1813, JOHN 1816, BERENDT 1830, GRAVENHORST 1835, SCUDDER 1889 and many others), but other fossilized resins as well (e.g. Scheuchzer 1708, Sendelius 1722, Bloch 1776, Brydone 1774, Dalman 1826, Hope 1836, HAGEN 1850).

The first comparisons of amber found in adjacent parts of Europe were being done as early as the $19^{\text {th }}$ century (STASZIC 1815 , ROBERT 1838 , STEINBECK 1841, HAGEN 1874).

The increase in knowledge of the geology and chemistry of amber and its inclusions resolved some old questions and debates, but a number of new ones arose. One relates to the distinction of amber from various deposits around the Baltic Sea, but also in Germany (Bitterfeld in Saxony), Belarus and Ukraine (the Rovno region). The debate surrounding this question has yet to be concluded. Nevertheless, chemical analysis of the main compound of these deposits, i.e. the resin (succinite in the geochemical nomenclature, predominant over all the other accessory resins found with it), has shown all these ambers to be very similar to one another. On the basis of the published data (RASCHER et al. 2008, Bogdasarov 2010, Dunlop et al. 2010, Perkovsky et al. 2010, Weitschat \& Wichard 2010), the similarities and differences of the resins accumulated around the Baltic Sea and in more remote localities can be discussed.

The paper is dedicated to Professor Ryszard Szadziewski, eminent Polish dipterologist and amber researcher.

\section{INCLUSIONS OF DIPTERA IN BALTIC AMBER OF DIFFERENT GEOGRAPHICAL PROVENANCE}

At present, there is no doubt that amber from Bitterfeld (Saxonian amber) is contemporaneous with Baltic amber, i.e. that it originated in the Eocene and that it belongs to the Baltic amber group (WEITSCHAT 1997, 2008, STANDKE 2008, RASCHER et al. 2008, Dunlop 2010, SonTAG \& SZADZIEWSKi 2011). Like the deposits of Baltic amber around the Gulf of Gdańsk it has been redeposited, and comes from the southern banks of the Eocene Peritethys Sea, which covered this part of Europe in those times.

The age and origin of the Baltic amber deposits in north-western Ukraine is still a controversial matter. Recent interpretations (BOGDASAROV 2010) make it contemporaneous with the Baltic amber from the Gulf of Gdańsk. But the question to be resolved is this: which deposits came into being as a result of the glacial redeposition of 
amber from the north, and which deposits originated in the hypothetical delta on the southern shores of the Tethys Sea, i.e. from the Ukrainian Crystalline Shield area? (BOGDASAROV 2006; 2010). The suggested collective description for the main type of resin found in this vast area (succinite) is resin from the Baltic-Dniepr amberiferous province (BOGDASAROV 2010).

The mineralogical and geological data and their interpretations are also supported by palaeoentomological research and interpretations of data provided by studies of inclusions.

The entomological investigations into Bitterfeld amber inclusions, which started in the 1980s, revealed mostly the same species as are known from Gulf of Gdańsk amber, but a few unique species as well. Notwithstanding that amber from the Gulf of Gdańsk has been studied for 200 years, the species described from Bitterfeld amber were identified among the inclusions in amber from the Gulf of Gdańsk. If Bitterfeld amber had been treated as Eocene from the outset, the number of species described from this area would have been lower, but the postulated Miocene age of this amber prevented scientists from describing common species, and even this small difference resulted in descriptions of separate taxa.

The insect inclusions in amber from the Rovno deposit have been studied since the year 2000, and some conclusions can be drawn from the results. After a faunistic review of the Formicidae from Rovno amber, DLUSSKY \& PERKOvSKY (2002) stated that $74 \%$ of the taxa were the same as those in amber from the Gulf of Gdańsk and that $26 \%$ were new, which led them to conclude that the Rovno deposit were autochthonous. They added that amber from the Rovno deposit differed from Gulf of Gdańsk amber, because if the new collection contained more than $2-5 \%$ of specimens representing new taxa, this meant that it would be a different deposit. In our opinion, this statement is rather the result of the intensity of research and extant taxonomic knowledge of the group. A recent comparison of ant inclusions based on larger samples from various collections housing inclusions of different geographical provenance (DLUSSKY \& RASNITSYN 2009) revealed that $10 \%$ (17 species) of all recorded Formicidae ants are common to all types of amber. In each representative collection these species account for more than $80 \%$ of the total number of inclusions. Hence, DLUSSKY \& RASNITSYN (2009) concluded that it seemed most likely that these ant faunas came into existence autochthonously in different habitats of an approximately equal age (on the geological scale).

The Diptera appears to be one of the best described groups of insects reported from Baltic amber. Hence, existing lists of fly taxa entombed in the Eocene resin of Europe, especially those from the Baltic amber group, appear to be reliable. An exhaustive list of Ceratopogonidae taxa reported from Baltic amber from the Gulf of Gdańsk, Ukraine and Germany (SONTAG \& SZADZIEWSKI 2011) enables one to compare the taxonomic diversity and similarity of these flies from inclusions collected in different geographical areas. 
Not all groups have been worked up to the same level, but thanks to the efforts of Professor Ryszard SZADZIEWSKI (SZADZIEWSKI 1984, 1985, 1986, 1988, 1993, 1998, 2005a, b, 2008, SZADZIEWSKI et al. 2007, SONTAG \& SZADZIEWSKI 2011), Ceratopogonidae is one of the best groups for such comparisons. Among 109 known species from Baltic amber (87 were described by SZADZIEWSKI), 86 were described from the Gulf of Gdańsk deposit, 22 from Bitterfeld (SzADZIEWSKI 1993) and one from the Rovno deposit (SONTAG \& SZADZIEWSKI 2011: Table 1, p. 796).

SONTAG \& SZADZIEWSKI (2011) studied the collection of Ceratopogonidae in Baltic amber from the Rovno deposit housed at the Schmalhausen Institute of Zoology, National Academy of Sciences of Ukraine (SONTAG \& SZADZIEWSKI 2011). Of 714 Ceratopogonidae specimens from the deposit in Rovno, 197 were placed in 30 species. Only two specimens represent a newly described species Leptoconops rovnensis SONTAG et SZADZIEWSKI, 2011 (SONTAG \& SZADZIEWSKI 2011). That study indicated that new specimens found from the Rovno deposit make up just $1 \%$, which is an even lower percentage than that postulated by DLUSSKY \& PERKOVSKY (2002). The description of the collection of ceratopogonids in Rovno amber (SONTAG \& SZADZIEWSKI 2011) leaves no doubts and demonstrates unequivocally that amber from the Rovno area belongs to the Baltic amber group. Amber from the Gulf of Gdańsk yielded 88 species of Ceratopogonidae, 23 of which are also known from the Bitterfeld deposit, and 26 from the Rovno deposit. In addition, 15 species are common to amber from the Bitterfeld and Rovno deposits. However, a statistical approach to inclusions in Baltic amber from various deposits and collections will always show up differences (ZHERIKHIN \& ESKOV 2007, SzWEDO \& SONTAG 2009, SonTAG \& SZADZIEWSKI 2011). The special treatment of amber found in a particular deposit would result in names like Gdańsk amber, Możdżanowo amber, Yantarnyi amber, Palanga amber, etc., differentiated as separate types, which is patently absurd. We agree that at least part of the amber from the Bitterfeld and Rovno deposits had formed autochthonously, in different habitats of variable Baltic amberiferous forest(s), under diverse ecological and habitat conditions. However, the observed differences seem to reflect ecological, environmental and taphonomic conditions rather than age.

Of course, the use of the deposit name is justified, but placing different types of amber in catalogues is not reasonable. Taking into consideration the area covered by amberiferous forest(s), from the Canadian Arctic to Fenno-Sarmatia, and from Spitsbergen to southern banks of the Tethys Sea (SzWEDO 2012), it is evident that the various habitats and types of amber forests present during the Eocene, with their diverse floristic compositions (as proven by the presence of accessory resins and pollen inclusions), resulted in the heterogeneity of inclusions. The amber samples we are studying now are mixtures of various allochthonous resins, transported to one place from various sites in vast ancient river basins, differing in relief, climate and biota (ZHERIKHIN \& ESKOV 2007). Even if the inclusions represent the considerable variability of the forests and their habitats, 
and even if we can differentiate and recognize inclusions characteristic of various environments, habitats and geographical regions, at present we have to accept that it is one single taphocoenosis - the taphocoenosis of Baltic amber.

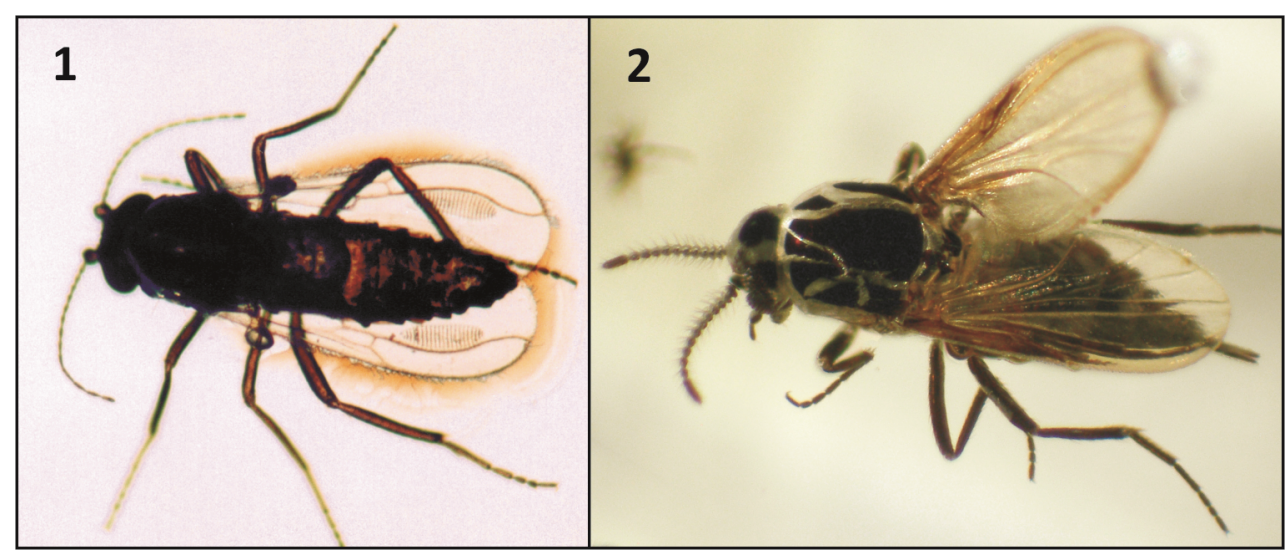

Figs 1, 2. 1 - Eohelea miocaenea SZADZIEWSKI, 1993 - a biting midge with characteristic stridulatory organ on the wing (perfect as "marker taxon"). It was formerly "marker taxon" for Bitterfeld deposit since 1993. In the year 2000 it was found in amber from Gulf of Gdańsk deposit and in year 2011 in amber from Rovno deposit. 2 - Leptoconops rovnensis SONTAG et SZADZIEWSKI, 2011 - "marker taxon" for amber from Rovno deposit and 109th species for taphocoenosis of Ceratopogonidae from Baltic amber.

The presence of lower rank taxa, genera and species of "marker taxa", could reveal the differentiation of Baltic amberiferous forest biota, and these are more important for analyses of amber faunas than generalized taxonomic lists (ZHERIKHIN \& ESKOV 2007). Insofar as common species provide information, studies of Ceratopogonidae from Baltic amber indicate that even "marker taxa" may be ephemeral. From 1988 to 1993, 86 species of biting midges from Gulf of Gdańsk amber were "marker taxa" for the deposit; by 1993 only 73 species remained as such, and since 2011 only 54 species of Ceratopogonidae are "marker taxa" for amber from this area.

One more reason for using the term Baltic amber is the lack of physical (e.g. FTIR spectra) or chemical methods permitting the identification of amber from particular deposits. Studying Baltic amber from various collectors and collections, it is almost impossible to identify the deposits from which the amber came if the pieces are not properly labelled. In fact, we do not know how many species described from Baltic amber in fact come from amber from the Rovno deposit. Rovno amber is Rovno amber as long as it stays in Ukraine; once it crosses the country's borders it becomes Baltic amber. 


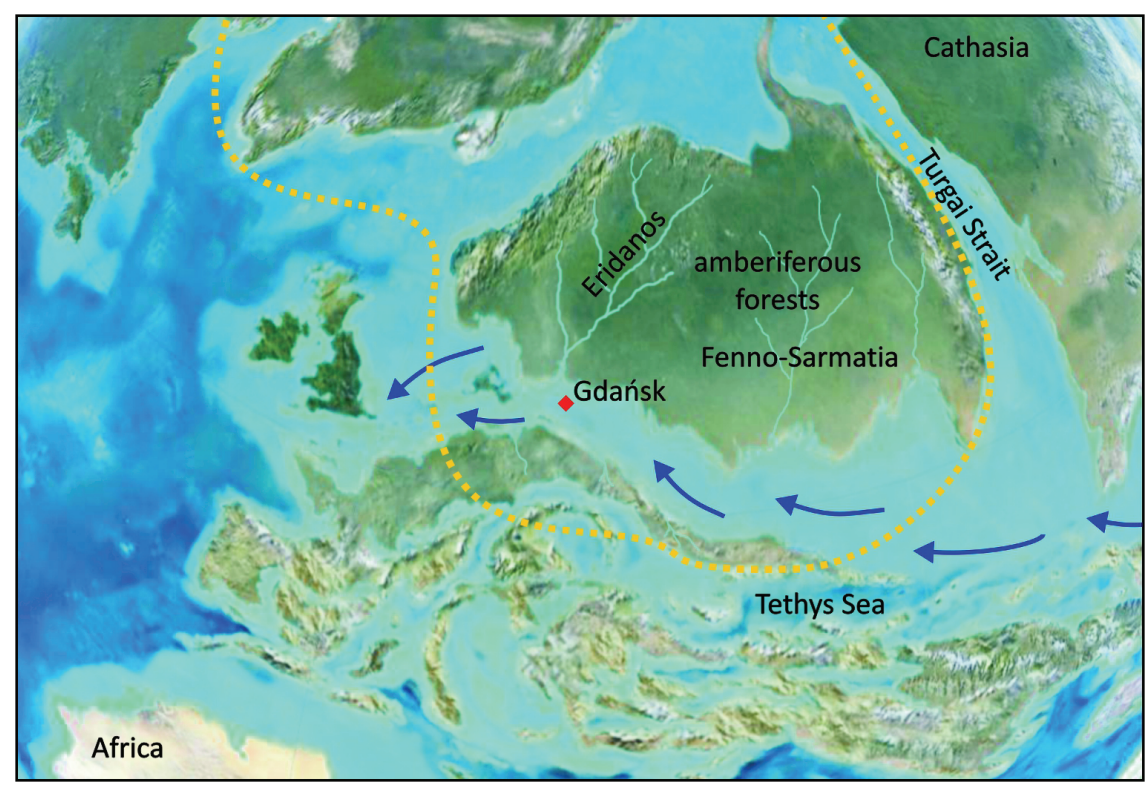

Fig. 3. Area of the amberiferous forests of the Fenno-Sarmatia during the Eocene. Yellow dotted line - borders of forest, dark blue arrows - prevailing direction of sea currents. Palaeogeographic reconstruction after Ron Blakey (Google Earth).

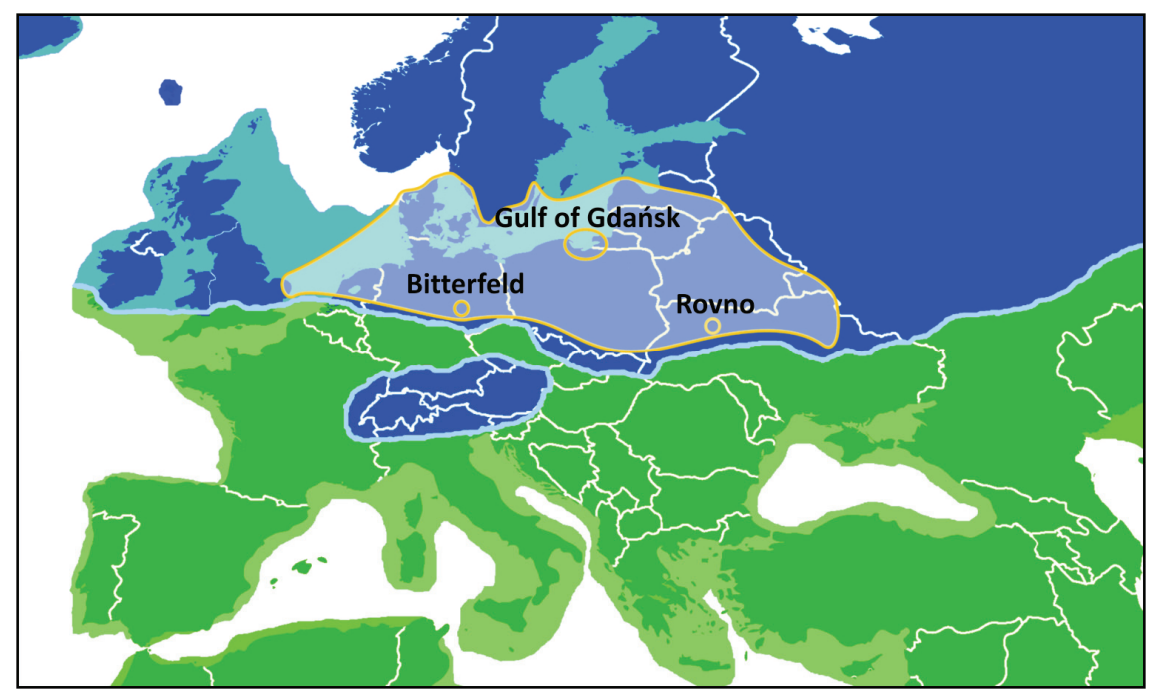

Fig. 4. Dispersion of Baltic amber during the glaciations (Pleistocene). Light blue line - maximum range of glacier, yellow line - range of amber deposits transported by the glacier, yellow circles places of accumulation of the Baltic amber. 


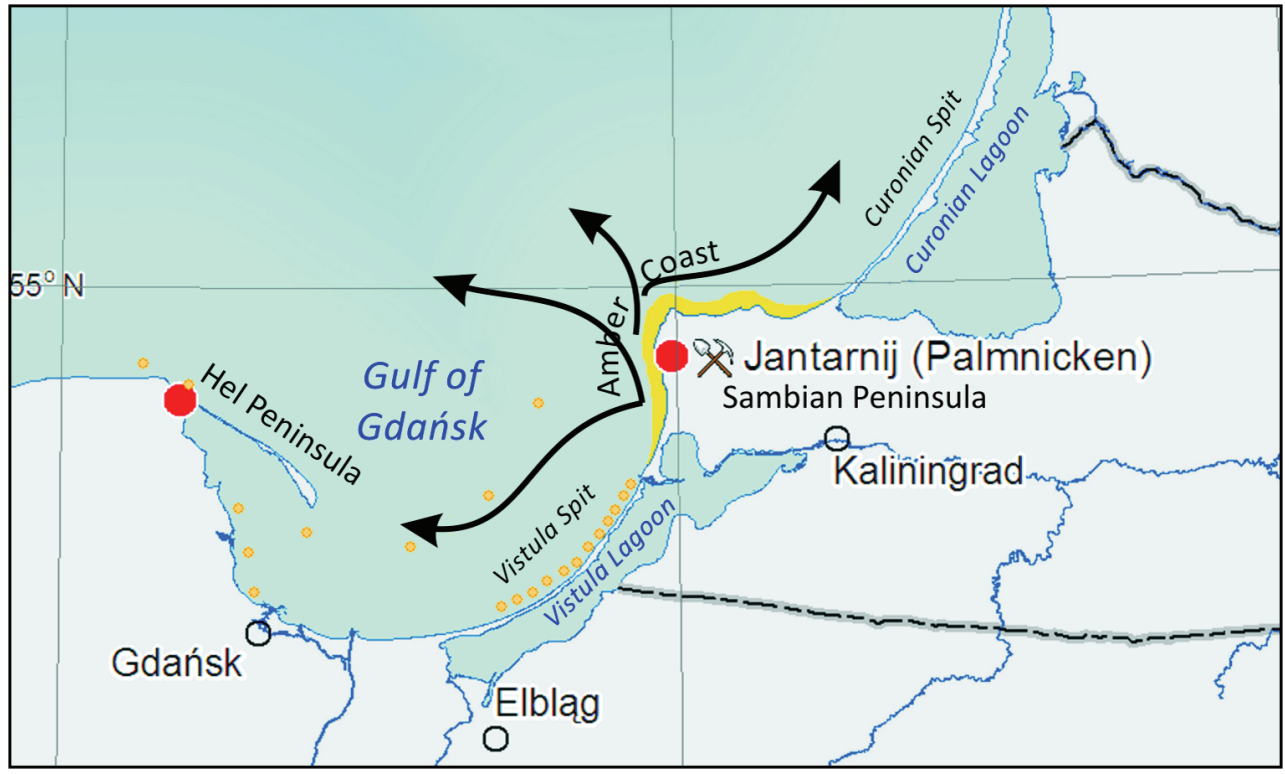

Fig. 5. Area of Gulf of Gdańsk and directions of transportation of amber by the sea currents. Red dots - Eocene deposits of amber.

Table. Decreasing of "marker taxa” for particular deposits.

\begin{tabular}{|l|c|c|c|}
\hline \multicolumn{1}{|c|}{$\begin{array}{c}\text { Ceratopogonidae in Baltic amber } \\
(109 \text { species })\end{array}$} & Gulf of Gdańsk & Bitterfeld & Rovno \\
\hline described from the deposit & 86 & 22 & 1 \\
\hline found in the deposit & 88 & 43 & 30 \\
\hline "marker taxa" since 1993 & 73 & 22 & - \\
\hline "marker taxa" in December 2013 & 54 & 17 & 1 \\
\hline
\end{tabular}

\section{REFERENCES}

AURIFABER A. 1551. Succini historia: Kurzer und gründlicher Bericht, woher der Agtstein oder Börnstein ursprünglich komme, dass er kein Baumharz sey, sondern ein Geschlecht des Bergwachs, und wie man jenen manigfaltiglich in Arzneyen möge gebrauchen. Konigsberg, $92 \mathrm{pp}$.

BERENDT G.C. 1830. Die Insekten im Berstein. Ein Beitrag zur Thiergeschichte der Vorwelt. Nicolai, Danzig, $38 \mathrm{pp}$.

BLOCH D. 1776. Beytrag zur Naturgeschichte des Kopals. Beschäftigungen der Berlinischen Gesellschaft Naturforschender 2: 91-196, tab. iii-v. 
Bock F.S. 1767. Versuch einer kurzen Naturgeschichte des Preussischen Bernsteins, und einer neuen wahrscheinlichen Erklärung seines Ursprunges. Königsberg, 146 pp.

BocK F.S. 1783. Versuch einer wirthschaftlichen Naturgeschichte von dem Königreich Ost- und West-Preussen. Dessau 2: 196-197.

BOEHMER G.R. 1788. Bibliotheca scriptorum historiae naturalis oeconomiae aliarumqve artium ac scientiarum ad illam pertinentium realis systematica. Lipsiae 1: 468-477.

Bogdasarov M.A. 2006. Problema obrazovanija yantara i drugikh iskopaemykh smol. Geologomineralogichni Visnik 2: 17-26. [In Russian].

BogdasARov M.A. 2010. Yantar i drugie iskopaemye smoly Evrazii: Monografiya. Brestskiï Gosudarstvennyï Universitet imieni A.S. Pushkina, Brest, 263 pp. [In: Russian].

BREYN J.P. 1728. Observatio de succinea gleba, plantae cujusdam folio impraegnata, rarissima. Philosophical Transactions 34: 154-156.

BRYDONE P. 1773. A tour through Sicily and Malta, in a series of letters to William Beckford, Esq., of Somerly in Suffolk. Vol. 1. London, 374 pp.

BuRMEISTER C.H.C. [HÜNEFELD L.] 1831. Derselbe über Bernsteininsecten. Isis, Oken, 1100.

DALMAN J.W. 1826. Om Insekten inneslutne i copal; jemte beskrifning på några deribland förekommande nya slägten och arter. Kongliga Svenska Vetenskaps-Akademiens Handlingar 1825 [1826]: 375-410.

DARWIN C. 1859. On the origin of species by means of natural selection, or the preservation of favoured races in the struggle for life. John Murray, London, $502 \mathrm{pp}$.

DE BonnaC J.L. D'Usson 1730. Memoire sur l'ambre jaune. Histoire de l'Académie royale des sciences, avec les mémoires de mathématique et de physique 1705: 41-44.

DLUSSKY G.M., RaSNitsyn A.P. 2009. Ants (Insecta: Vespida: Formicidae) in the Upper Eocene amber of Central and Eastern Europe. Paleontological Journal 43: 1024-1042.

Dunlop J.A. 2010. Bitterfeld amber. [In:] PENNEY D. (ed.). Biodiversity of fossils in amber from the major world deposits. Siri Scientific Press, Manchester: 57-68.

FALIMIRZ S. 1543. O ziołach y o mocy ich. F. Ungler, Kraków, 380 pp.

Fothergill J. 1746. An extract of John Fothergill, M. D. licentiate of the Royal College of Physicians, London, his essay upon the origin of amber. Philosophical Transactions 43: 21-25.

GERMAR E.F. 1813. Insecten in Berstein eingeschlossen, beschrieben aus dem academischen Mineralien-Cabinet zu Halle. Magazin der Entomologie 1: 13-18.

GöBEL S. 1558. De succino libri II, quorum prior theologicus, posterior de Succini origine agit. Francofordi ad Maenium, $65 \mathrm{pp}$.

GRAVENHORST I.L.C. 1835. Bericht über die im Bernstein erhaltenen Insekten der physikalischökonomischen Geselschaft zu Königsberg. Übersicht der Arbeiten und Veränderungen der Schlesischen Geselschaft für Vaterländische Kultur 1834: 88-95.

Grew N. 1681. Musaeum Regalis Societatis. Or a catalogue [et] description of the natural and artificial rarities belonging to the Royal Society and preserved at Gresham College; made by Nehemjah Grew M.D. Fellow of the Royal Society and of the College of Physitians. Whereunto is subjoyned the Comparative anatomy of stomachs and guts, by the same author. London, $386 \mathrm{pp}$.

Hagen H.A. 1850. Das Bernsteinland. Neue Preussische Provinzial-Blätter 10: 75-82, 120-125.

HAgen H.A. 1874. On amber in North America. Proceedings of the Boston Society of Natural History 16: $296-301$.

HaRTMAnN P.J. 1677. Succini prussici physica et civilis historia cum demonstratione ex autopsia et intimiori rerum experientia deducta. Francofurti, 291 pp.

HARTMANN P.J. 1699. Succincta succini prussici historia et demonstratio. Berolini, 48 pp.

HELWING G.A. 1717-1720. Lithographia angerburgica, sive Lapidum et fossilium in districtu Angerburgensi et ejus vicinia ad trium vel quatuor milliarium spatium in montibus, agris, arenofodinis et in primis circa lacuum littora et fluviorum ripas, collectorum brevis et succincta consideratio. Additis rariorum aliquot figuris aeri incisis, cum praefatione autoris et indicibus 
necessariis. Pars II in qua de lapidibus figuratis ad triplex regnum minerale, vegetabile et animale redactis aliisque fossilibus in districtu angerburgensi ejusque vicinia noviter detectis ... de origine lapidum literas exprimentium ... disseritur; additis iconibus rariorum. Lithographia angerburgica, sive Lapidum et fossilium in districtu Angerburgensi \& ejus vicinia Regimonti, Lipsiae, $96+132 \mathrm{pp}$.

HOPE F.W. 1836. Observations on succinic insects. Transactions of the Entomological Society of London 1: 133-147.

JOHN J.F. 1816. Naturgeschichte des Succins, oder des sogenannten Bernsteins: nebst Theorie der Bildung aller fossilen, bituminösen Inflammabilien des organischen Reichs und den Analysen derselben. 1-2, Köln, 438+125 pp.

LINNAEUS C. 1758. Systema naturæ per regna tria naturæ, secundum classes, ordines, genera, species, cum characteribus, differentiis, synonymis, locis. Tomus I. Editio decima, reformata. Salvius, Holmiæ, [1-4]+1-824 pp.

MerCATI M. 1717. Michaelis Mercati samminiatensis Metallotheca opus posthumum, auctoritate, \& munificentia Clementis XI. pontificis maximi e tenebris in lucem eductum; opera autem, \& studio Joannis Mariae Langisii archiatri pontificii illustratum. Romae, $378+18$ pp.

MÜNSTER S. 1554. Cosmographia. Beschreibung aller Lender durch Sebastianum Münsterum: in welcher begriffen aller Voelker, Herrschaften, Stetten, und namhafftiger Flecken, herkommen: Sitten, Gebreüch, Ordnung, Glauben, Secten und Hantierung durch die gantze Welt und fürnemlich Teütscher Nation. Basel, $1163 \mathrm{pp}$.

Perkovsky E.E., Rasnitsyn A.P., Vlaskin A.P., TARAsChuk M.V. 2007. A comparative analysis of the Baltic and Rovno amber arthropod faunas: representative samples. African Invertebrates 48: 229-245.

Perkovsky E.E., Zosimovich V.Yu., Vlaskin A.P. 2010. Rovno Amber. [In:] Penney D. (ed.). Biodiversity of fossils in amber from the major world deposits. Siri Scientific Press, Manchester: 116-136.

Pluche N.-A. 1748. Schau-Platz der Natur oder Gespräche von der Beschaffenheit und den Absichten der Naturlichen Dinge etc., 3, Wienn und Nürnberg, 592 pp.

RASCher J., Wimmer R., Krumbiegel G., SCHMiedel S. (eds). 2008. Bitterfelder Bernstein versus Baltischer Bernstein: Hypothesen, Fakten, Fragen. II. Bitterfelder Bernsteinkolloquium. Exkursionsführer der Deutschen Gesellschaft für Geowissenschaften 236: 1-166.

ROBERT E. 1838. Lettre sur les observations faites en Danemarck, en Norwege et en Suede, et dans laquelle il parle du succin. Bulletin de la Societe Geologique de France 9: 114-118.

SCHEUCHZER J.J. 1708. Beschreibung der Natur-Geschichten des Schweizerlands. Dritter Theil. Enthaltende vornemlich eine Ober die hochsten Alpgebirge An. 1705 getahne Reise. Zurich, $208 \mathrm{pp}$.

SCUDDER S.H. 1882. A bibliography of fossil insects. Cambridge, Mass., University Press, John Wilson and Son, $47 \mathrm{pp}$.

SENDELIUS N. 1722. De succino indico, ad virum nobilissimum atque experientissimum dominum Johannem Philippum Breynium epistola, prodromi loco electrologiae suae propediem edendae scripta. Breynii Melonibus petrefactis montis Carmel, pp.: 35-48.

SENDELIUS N. 1742. Historia succinorum corpora aliena involventium et naturae opere pictorum et caelatorum ex regiis Augustorum cimeliis Dresdae conditis aeri insculptorum conscripta. Lipsiae, $328 \mathrm{pp}$.

Sontag E., SzAdZIEwSKi R. 2011. Biting midges (Diptera: Ceratopogonidae) in Eocene Baltic amber from the Rovno region (Ukraine). Polish Journal of Entomology 80: 779-800.

STANDKE G. 2008. Bitterfelder Bernstein gleich Baltischer Bernstein? Eine geologische Raum-ZeitBetrachtung und genetische Schlussfolgerungen. Exkursionsführer der Deutschen Gesellschaft für Geowissenschaften 236: 11-33. 
STASzic S. 1815. O ziemiorództwie Karpatów i innych gór i równin Polski. W Drukarni Jego Ces. król. Mości Rządowei, Warszawa, 390 pp.

STEINBECK A. 1841.Ueber die Bernsteingewinnung bei Brandenburg an der Havel. 1 2. Brandenburg. Neue Notizen aus dem Gebiete der Natur- und Heilkunde (303) 14: 257-263.

SzADZIEWSKI R. 1984. Niezwykłe narządy strydulacyjne u eoceńskich muchówek z rodziny Ceratopogonidae (Diptera). Wiadomości Entomologiczne 5: 37-40.

SzAdZiEwski R. 1985. Biting midges of the genus Eohelea Petrunkevitch (Insecta, Diptera, Ceratopogonidae) from Baltic amber (in the collection of the Museum of the Earth). Prace Muzeum Ziemi 37: 123-130.

SZADZIEWSKI R. 1986. Genera of the Baltic amber Ceratopogonidae and their recent distribution. [In:] First International Congress of Dipterology, Abstract Volume, Budapest, p.: 236.

SzADZIEWSKI R. 1988. Biting midges (Diptera, Ceratopogonidae) from Baltic amber. Polskie Pismo Entomologiczne 58: 3-283.

SZADZIEWSKI R. 1993. Biting midges (Diptera, Ceratopogonidae) from Miocene Saxonian amber. Acta Zoologica Cracoviensia 35: 603-656.

SZADZIEWSKI R. 1998. A new species of the predaceous midge genus Metahelea from Baltic amber (Diptera: Ceratopogonidae). Polskie Pismo Entomologiczne 67: 245-253.

SzADZIEWSKI R. 2005. Pierwszy fosylny kuczman plemienia Sphaeromiini (Diptera: Ceratopogonidae). Dipteron. Bulletin of the Dipterological Section of the Polish Entomological Society 21: 37-38.

SZADZIEWSKI R. 2005. The first fossil species in the predaceous midge tribe Sphaeromiini (Diptera: Ceratopogonidae). Polskie Pismo Entomologiczne 74: 363-368.

SZADZIEWSKI R. 2008. Age and recent distribution of extant genera of Ceratopogonidae (Diptera) present in the fossil record. Alavesia 2: 87-99.

SzADZIEWSKi R., GiŁKa W., SonTAG E. 2007. First description of males from Eocene Baltic amber in the fossil genus Mantohelea (Diptera: Ceratopogonidae). Alavesia 1: 37-40.

SzwEdo J. 2012. Life in the Eocene forests. World Amber Council Seminar. Gdańsk the World Amber Capital, Gdańsk, May 18-19.2012. Mayor's Office for City Promotion, City Hall of Gdańsk, Gdańsk, pp.: 60-74.

Szwedo J., SONTAG E. 2009. The traps of the 'amber trap'. Amber-trapped insects trap scientists with enigmas. [In:] Berning B., Podenas S. (eds). Amber: Archive of the deep time. Denisia, 26, zugleich Kataloge der oberösterreichischen Landesmuseen Neue Serie 86: 155-169.

VALENTINI M.B. 1714. Museum museorum oder Vollstandige schau bühne aller materialien und specereyen etc. Zweyte edition. Vols 1-3. Franckfurt am Mayn, 520+196+218 pp.

WeITSCHAT W. 1997. Bitterfeld Bernstein - ein eozäner Bernstein auf miozäner Lagerstätte. [In:] GANZELEWSKi M., Rehren T., Slotta R. (eds). Neue Erkentnisse zum Bernstein. Internationales Symposium in Deutschen Bergbau-Museum. Metalla, Veröffentlichungen aus dem Deutschen Bergbau-Museum Bochum, Sonderheft 66: 57-62.

Weitschat W. 2008. Bitterfelder und Baltischer Bernstein aus paläoklimatischer und paläontologischer Sicht. [In:] Rascher J., Wimmer R., Krumbiegel G., Schmiedel S. (eds). 2008. Bitterfelder Bernstein versus Baltischer Bernstein: Hypothesen, Fakten, Fragen. II. Bitterfelder Bernsteinkolloquium. Exkursionsführer der Deutschen Gesellschaft für Geowissenschaften 236: 88-97.

Weitschat W., Wichard W. 2010. Baltic Amber. [In:] Penney D. (ed.). Biodiversity of fossils in amber from the major world deposits. Siri Scientific Press, Manchester: 80-115.

ZHERIKHIN V.V., ESKOV K.YU. 2007(2006). On the real proportions of the main arthropod groups in the Baltic amber fauna, based on representative sampling. Arthropoda Selecta 15: 173-179.

Received: 9 November 2013

Accepted: 30 November 2013 